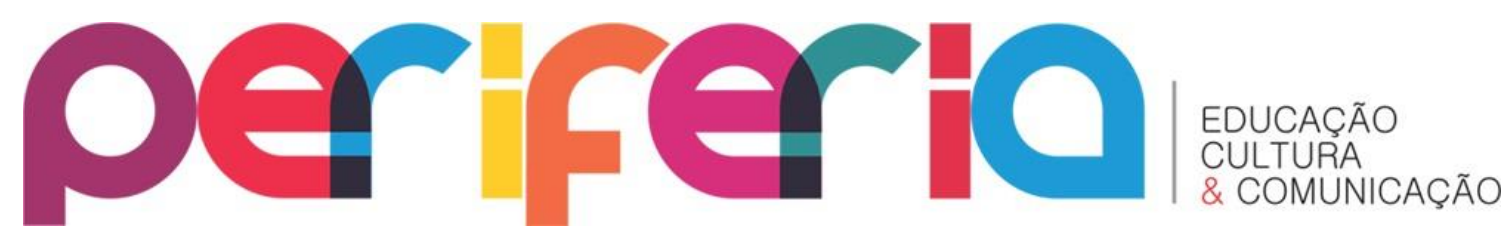

\title{
A REPRESENTAÇÃO DO NEGRO NA LITERATURA INFANTIL BRASILEIRA
}

\section{The representation of the Black in Brazilian's children literature}

\author{
Jessica Oliveira Farias ${ }^{1}$
}

\begin{abstract}
RESUMO: O presente artigo apresenta uma pesquisa qualitativa, que teve como foco a análise da trajetória da representação das personagens negras na produção literária infantil brasileira, do início do século XX até os primeiros anos do século XXI. Tivemos como objetivo a busca por obras que valorizassem a identidade afro-brasileira para um trabalho com africaneidades e relações sociais nas séries iniciais do ensino fundamental. Percebemos que a literatura, como reflexo da sociedade, excluiu ou tratou os afrodescendentes de forma diferenciada ao longo de muitos anos na história do Brasil. Considerando os pressupostos de autores como Sousa (2001), Gouvêa (2005), Hunt (2010) e Silva e Silva (2011) para nortear nosso estudo, apresentamos resultados que demonstram como a representação do negro na Literatura infantil passou por fases como omissão; estereotipação; e deturpação da imagem, do caráter e inteligência. Além disso, analisamos algumas opiniões acerca da censura nos acervos literários escolares e citamos exemplos de textos que podem ser explorados em um trabalho pedagógico preocupado com as relações étnicas no ambiente escolar.
\end{abstract}

Palavras-chave: Literatura infantil, Identidade negra, Representações do negro na literatura, Censura, Acervos literários escolares

ABSTRACT: This article presents a qualitative research that focused on the representation of the black characters in Brazilian children 's literary production from the beginning of the 20th century until the first years of the 21 st century. Our goal was searching for books that value the Afro-Brazilian identity for a pedagogical work with Africanities and social relations in the initial grades of elementary school. We noticed that literature, as a reflection of society, has excluded or treated Afrodescendants differently over many years in the history of Brazil. Considering the assumptions of authors such as Sousa (2001), Gouvêa (2005), Hunt (2010) and Silva e Silva (2011) to guide our study, we present some results that demonstrate how the black representation

\footnotetext{
${ }^{1}$ Professora do Departamento de $1^{\circ}$ segmento do Colégio Pedro II e mestranda do Curso de mestrado profissional em práticas da educação básica do Colégio Pedro II.
} 


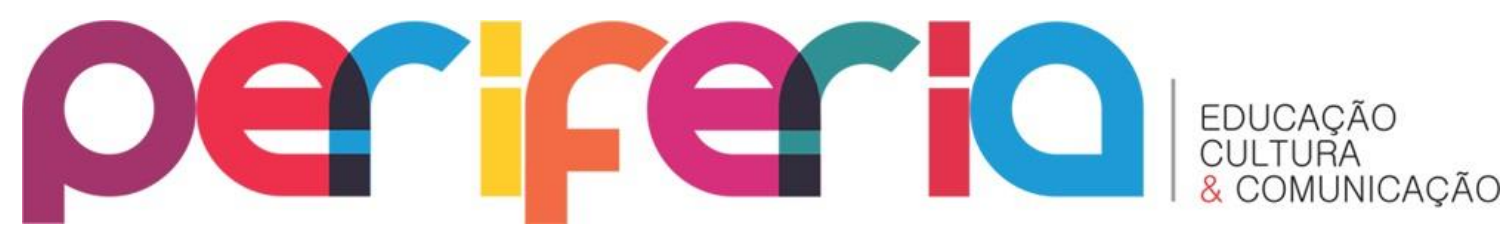

in children's literature went through phases as omission; stereotyping; and misrepresentation of image, character and intelligence. In addition to that, we have also analyzed some opinions about censorship in school literary collections and named examples of texts that can be explored in a pedagogical work concerned with ethnic relations in the school environment.

Keywords: children's literature, black identity, black representations in literature, censorship, school's literary collections

\section{A REPRESENTAÇÃO DO NEGRO NA LITERATURA PARA CRIANÇAS BRASILEIRAS}

No início do século XX, após a abolição da escravatura no Brasil, algumas representações do negro começam a aparecer na literatura, a princípio não relacionadas à importante contribuição cultural dos afrodescendentes para a história de nosso país, mas sim, com suas trajetórias de sofrimento e dor. A figura do negro era praticamente inexistente nos livros antes disso e, obviamente, não havia qualquer tipo de preocupação com a criança negra. Esta não tinha visibilidade alguma no cenário burguês, supostamente moderno e civilizado que aqui se procurava instaurar, como é possível observar no seguinte trecho:

[...] o que vimos foram preocupações relacionadas ao status burguês e à manutenção de uma versão idealizante de um Brasil equilibrado, moralista, cujos filhos, trabalhadores, e cujas famílias, bem constituídas, teriam livros e escolas que reforçassem esse padrão europeu de sucesso e de organização." (SILVA e SILVA, 2011, p. 4)

Desse modo, as autoras afirmam que com o país em ascensão econômica, adultos ou crianças pobres eram invisíveis frente à sociedade, pois as preocupações não eram voltadas para esses grupos. Para o negro era ainda pior, pois o fim da escravidão não eliminou também o preconceito. O mercado literário no Brasil era essencialmente ligado aos ideais das classes dominantes, o que, de certo modo, acontece até hoje. Assim, o que não era interessante ou estava relacionado às "raças inferiores", de acordo com os conceitos daquela época, permanecia velado. 


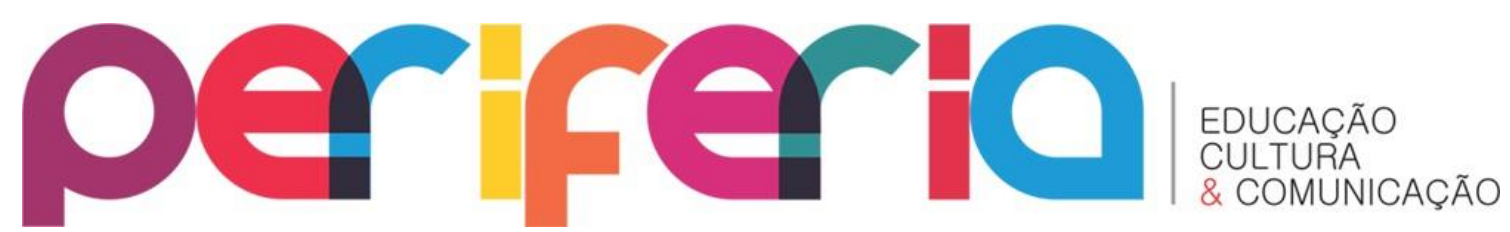

Nas obras literárias, basicamente, não havia personagens negros até $o$ Modernismo. Segundo Gouvêa (2005, p.79), "nas obras produzidas até a década de 1920 os personagens negros eram ausentes ou remetidos ao recente passado escravocrata”. Essa omissão acontecia por diversos motivos. Em primeiro lugar, pessoas negras foram consideradas inferiores em relação às brancas por muito tempo, em aspectos mentais, socioculturais e cognitivos. As teorias raciais, consideradas científicas, na época, justificavam a soberania dos brancos sobre às demais raças, como afirma Giarola

As teorias raciais apresentaram-se no século XIX como um discurso científico que buscava explicar as diferenças entre os grupos humanos, distanciando-se cada vez mais dos dogmas religiosos. Serviram como legitimadoras do imperialismo europeu, possibilitando a hierarquização da humanidade de forma que o homem branco ocupasse o topo da evolução da espécie, símbolo maior do progresso e da civilização. Essas ideias tiveram ampla difusão na sociedade europeia e não tardaram a se espalhar pelo mundo, ganhando adeptos nos Estados Unidos, Argentina, Brasil, entre outros. (2010, p. 7)

Logo, o uso de taxonomias biológicas para classificar as pessoas em raças superiores ou inferiores diminuía cada vez mais a importância do negro como ser social. As condições de desigualdade se tornaram mais fortalecidas com os processos de escravidão. Os negros não possuíam liberdade e eram propriedades de seus senhores, aos quais eram submissos e subservientes. Portanto, as marcas de inferioridade construídas historicamente faziam com que esses personagens fossem invisíveis nos livros de histórias, assim como eram também para a sociedade.

Em segundo lugar, havia a falta de um público leitor que se interessasse por qualquer informação relacionada ao cotidiano dos negros, já que a grande maioria dos afro descendentes pós Abolicionismo era analfabetos e, portanto, não compraria esses livros. Quanto aos brancos, segundo Castilho (2004, p. 104) "estavam do lado dos opressores e não poderiam dar atenção aos oprimidos". Ou seja, tanto por serem considerados inferiores, como por não possuírem recursos para o acesso à arte literária, os negros foram por muito tempo excluídos das páginas dos livros. 


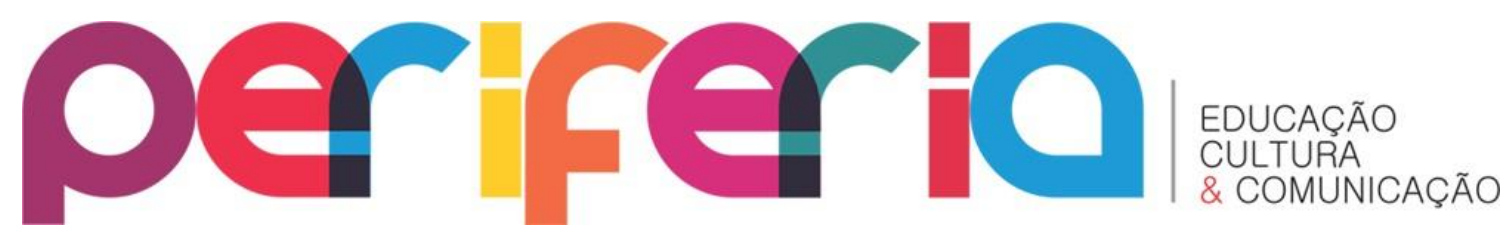

Esse quadro só começa a se modificar, com efeito, a partir de 1920, mais de trinta anos após o fim da escravidão. Depois do Modernismo, para Gouvêa (2005, p.79), "os personagens negros tornam-se frequentes, descritos de maneira a caracterizar uma suposta integração racial, hierarquicamente definida. " Assim, eles começam a surgir nas narrativas, porém, com representações estereotipadas, caracterizações superficiais e nomes que se limitavam a reforçar a cor de sua pele, como: negrinho, negrinha, o preto, a pretinha entre outros.

Um exemplo de representação estereotipada muito recorrente nos livros infantis dessa época eram as personagens das velhas e velhos negros. Estes eram na grande maioria coadjuvantes e estavam geralmente na posição de empregados, o que remetia ao recente passado escravocrata. As histórias do povo eram sempre contadas por eles, por meio de narrativas orais "carregadas de valor afetivo, contadas por pretas velhas, associadas à ingenuidade, ao primitivismo, apresentando uma estereotipia e simplificação características" (GOUVÊA, 2005, p.84). Assim, esses personagens reforçavam a significação do folclore nacional e da arte da contação de histórias para as crianças.

Nas obras de Monteiro Lobato, os personagens Tia Nastácia e Tio Barnabé são exemplos de negros velhos que resgatam o folclore através de suas histórias, costumes e crenças. De forma saudosista, tais personagens ocupavam um lugar à parte e diferenciado dos outros personagens nas narrativas, de forma sempre característica. Dentro de um contexto Modernista, Nastácia era uma figura que ia de encontro a esse novo Brasil progressista, ao reforçar aspectos da identidade nacional e valorizar práticas culturais que a modernização buscava deixar no passado. Gouvêa fala sobre essa dicotomia de opiniões quanto às tradições folclóricas em tempos de mudança

Lobato apontava a contradição entre o projeto de resgate da tradição oral e sua inadequação ao presente, na medida em que era associada à ignorância e à falta de criatividade. Lobato falava do fim de uma tradição, sepultada pelos valores da modernidade, que, ambiguamente, de um lado buscava recuperar as raízes nacionais e, de outro, enxergava nessas raízes as origens da ignorância que impediriam a construção de um Brasil moderno. (2005, p.85) 


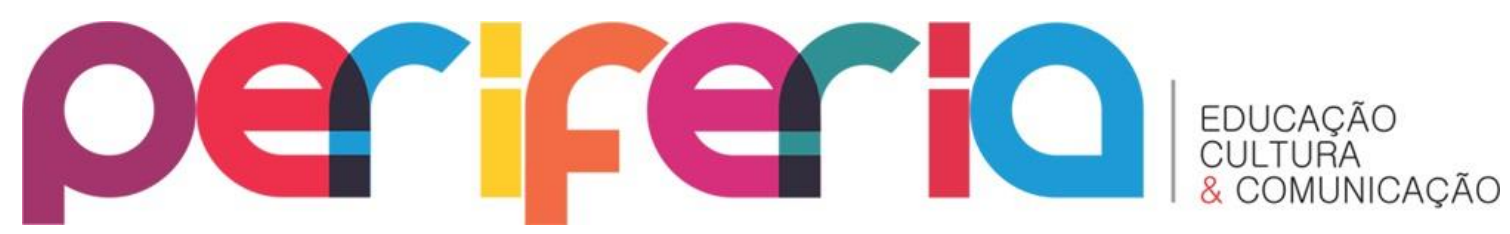

Desse modo, percebe-se que Lobato trazia à tona em seus textos a cultura mais tradicionalista do senso comum, que ia gradativamente ficando para trás. Porém, ao mesmo tempo, ele mostrava o distanciamento e desvalorização do saber popular em relação aos saberes eruditos, representado pela cultura do branco europeu, como nesta fala da personagem Emília, em Histórias de tia Nastácia: "Eu, francamente, passo essas tais histórias populares. Gosto mais é das de Andersen, das do autor do Peter Pan e das do tal Carroll, que escreveu Alice no País das Maravilhas. Sendo coisas do povo, eu passo..." (LOBATO, 1937, p. 14 e 15)

Em outros trechos da mesma obra, o conhecimento de tia Nastácia representando os costumes do negro, era satirizado como sendo do povo, inferior e tolo, tal qual podemos observar mais uma vez na fala da personagem Emília:

- Só aturo estas histórias como estudo da ignorância e burrice do povo. Prazer não sinto nenhum. Não são engraçadas, não têm humorismo. Parecem-me muito grosseiras e bárbaras - coisa mesmo de negra beiçuda, como Tia Nastácia. Não gosto, não gosto e não gosto. (1937, p. 31)

Observa-se que além de ter sua inteligência questionada, a aparência física da personagem negra também é mencionada com marcas preconceituosas. As ilustrações de Nastácia nas histórias destacam a desarrumação e sujeira de suas vestes, bem como seus traços físicos grotescos e por vezes assustadores. Dona Benta, a matriarca, representante do conhecimento do branco, erudito, também critica, as práticas orais antiquadas de contação de histórias de Nastácia, como podemos ver neste trecho do livro:

Nós não podemos exigir do povo o apuro artístico dos grandes escritores. O povo... Que é o povo? São essas pobres tias velhas, como Nastácia, sem cultura nenhuma, que nem ler sabem e que outra coisa não fazem senão ouvir as histórias de outras criaturas igualmente ignorantes, e passá-las para outros ouvidos, mais adulteradas ainda. (Lobato, 1937, p. 30)

Como podemos observar, apesar de Tia Nastácia estar numa posição privilegiada de protagonista juntamente com Dona Benta, as duas não possuíam relação 


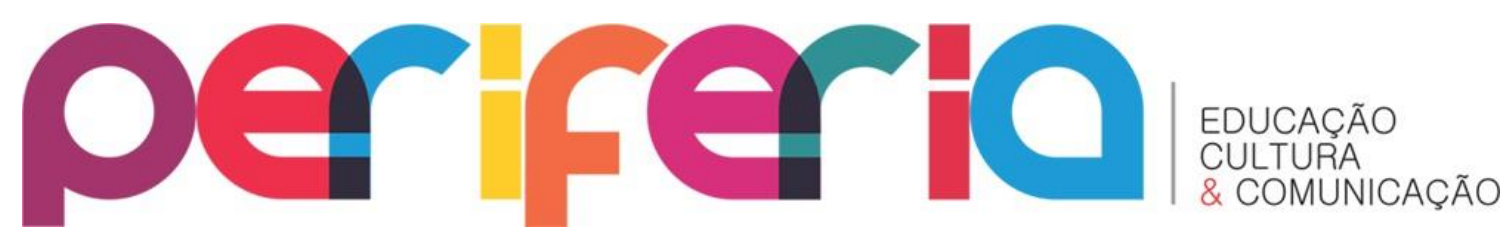

de igualdade. Tanto no texto quanto nas ilustrações, a personagem negra é inferiorizada, seja pela falta de instrução formal, ou por suas vestimentas e aparência física.

Enquanto os negros ou negras velhas das zonas rurais eram caracterizados como trabalhadores, afetuosos, contadores de histórias populares, últimos representantes do folclore nacional, a representação do negro da cidade era bem diferente. De modo contrário à imagem do velho, o negro jovem quase não aparece nas obras de literatura infantil. Isso porque este era visto como perigoso, ladrão, mendigo, um reflexo do jovem negro na sociedade urbana pós abolicionismo.

Os escravos mais velhos, moradores do campo, permaneceram em sua maioria trabalhando como empregados ou agregados para os seus ex-senhores, muitas vezes em troca de abrigo e comida. Enquanto isso, os jovens escravos moradores da cidade, recém- libertos, que não queriam se submeter à condição semelhante à que possuíam quando escravos, se encontravam sem casa, sem posses e muitas vezes sem trabalho. Este fato causou um grande aumento da marginalidade dessa porção da população negra da época. A suposta liberdade conquistada com a abolição dos escravos substituiu a noção de inferioridade, antes explicada pelas teorias raciais, pela desigualdade de nível cultural e intelectual como explica Souza:

Na verdade, o preconceito das sociedades centrais que se percebiam no século 19 como "racisticamente" superiores foi transformado em superioridade "cultural" precisamente pela contraposição entre a "racionalidade" (superior) e o "afeto" (inferior) típico das sociedades periféricas. O "racismo", no entanto, apesar de disfarçado, continua na visão culturalista que também, como em todo racismo, "essencializa" e torna homogêneos indivíduos e sociedades inteiras. (2011, p. 57).

Diante disso, observamos que a abolição da escravidão não proporcionou uma relação de conformidade entre brancos e negros. A falsa ideia de uma cor de pele ser superior à outra perdurou, se não por questões raciais, mas por questões de cultura e de costumes considerados mais civilizados. O que se buscava imprimir era um falso modelo de Brasil moderno, defensor de uma democracia entre as raças. Na verdade, 


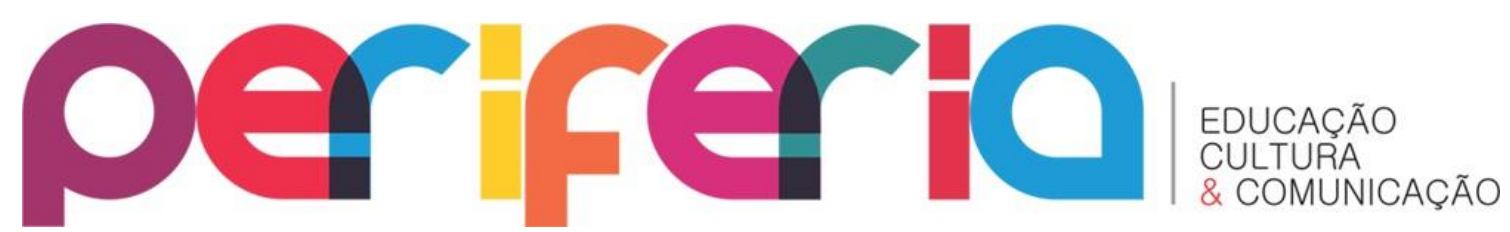

escondiam-se as reais imagens dos negros através de caracterizações generalistas. As relações de humilhação e exclusão eram sutilmente mascaradas na literatura infantil.

A caracterização negativa de personagens negros nos livros infantis permaneceu por mais algumas décadas, deixando gerações de crianças afrobrasileiras carentes de uma literatura que lhes representasse positivamente. $O$ menino marrom (1986) de Ziraldo é um exemplo de texto que apesar de retratar a amizade entre uma criança negra e uma branca, ao colocar o personagem negro como principal, valorizando a diversidade étnica no Brasil, acaba por corroborar em seu texto e ilustrações de maneira sutil com o preconceito. Por exemplo, vemos no seguinte trecho do livro: " [...] o menino cor-de-rosa resolveu perguntar: por que você vem todo o dia ver a velhinha atravessar a rua? E o menino marrom respondeu: Eu quero ver ela ser atropelada" (ZIRALDO, 1986, p.24). Como podemos observar, mais uma vez a figura do negro é marginalizada e caracterizado de forma negativa.

Mais tarde com a publicação de Menina bonita do laço de fita (1988) de Ana Maria Machado, essa abordagem começou a se modificar, com modelos positivos para um público que antes só se via majoritariamente mitificado ou desqualificado.

Desde então, as indústrias editoriais têm dedicado mais atenção ao público infantil negro. Muitos livros hoje em circulação que são direcionados às crianças abordam a importante contribuição da cultura afrodescendente para o nosso país. Essas leituras e ilustrações permitem que os jovens se sintam devidamente representados tanto em sua expressão física, ao valorizar sua beleza corporal, quanto em aspectos intelectuais, ao não subestimarem suas potencialidades.

\section{EM BUSCA DE OBRAS COM ENFOQUE NA IDENTIDADE NEGRA PARA O PÚBLICO INFANTIL}

Ao longo da história da literatura nacional, os personagens negros estiveram, em sua maioria, representados por estereótipos, que como já comentamos anteriormente, destacavam negativamente seus traços físicos e costumes de higiene, questionavam sua inteligência e os posicionavam em um lugar de marginalidade ou 


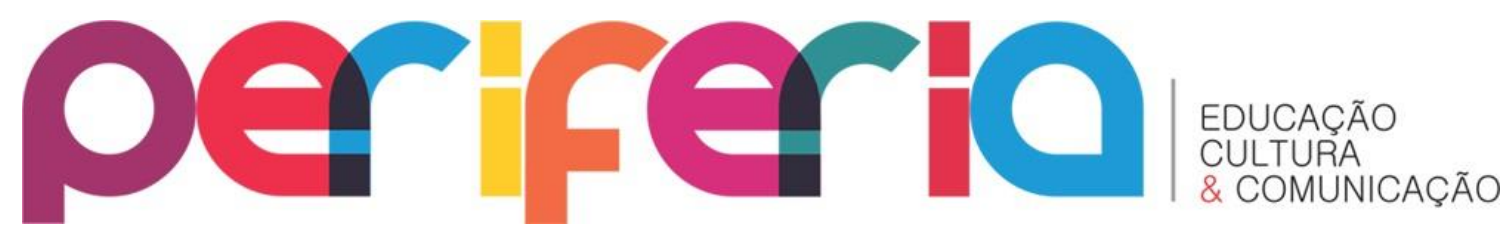

subserviência. Essas tendências permanecem, de certo modo, até hoje, principalmente devido às relações de poder e preconceito enraizadas historicamente na humanidade. Porém, para Silva e Silva (2011, p. 5), "Não devemos descartar tais obras, temos que revisitá-las sempre, buscando o entendimento de suas construções para que haja desenvolvimento intelectual." As autoras acreditam que, apesar de não podermos modificar o passado, podemos agora compreendê-lo de um modo diferente. É necessário, entretanto, dedicar atenção especial e tempo para discussão no momento da leitura de obras que deturpam a figura do negro com referências preconceituosas, para evitar que valores errôneos sejam reforçados. Logo, questionar, criticar e interpretar textos criados em outros tempos não deixa de ser importante, principalmente na escola, o primeiro ambiente multicultural e dialógico do qual todos fazemos parte em algum momento.

Atualmente, a literatura infantil tem se preocupado quanto à criação de obras que valorizem a identidade negra e mais importante, que mostrem aspectos culturais e históricos além da escravidão. Nas últimas décadas do século XX, começam a surgir novos livros de autoria nacional com propostas diferentes dos anteriores, agora defendendo uma nova representação da imagem do negro, mais fiel à realidade, prezando suas tradições e costumes.

Em Menina bonita do laço de fita (1988), a personagem negra é enaltecida por seus traços físicos considerados lindos por outros personagens, como vemos nesta passagem: "os cabelos enroladinhos e bem negros [...] A pele era escura e lustrosa, que nem o pelo da pantera negra na chuva". As ilustrações do livro têm um papel importante, pois representam as personagens negras sempre de maneira feliz, com roupas bonitas e penteados diferentes. Do mesmo modo, em Bruna e a galinha d'angola (2000), de Gercilga de Almeida, Bruna, personagem principal da estória, se sente sozinha; sua avó, então, percebendo a tristeza da neta, decide lhe contar algumas histórias míticas de origem africana que explicam a criação do mundo e exemplificam costumes culturais de seu povo. Mais uma vez, texto e ilustrações representam as personagens de forma positiva. 


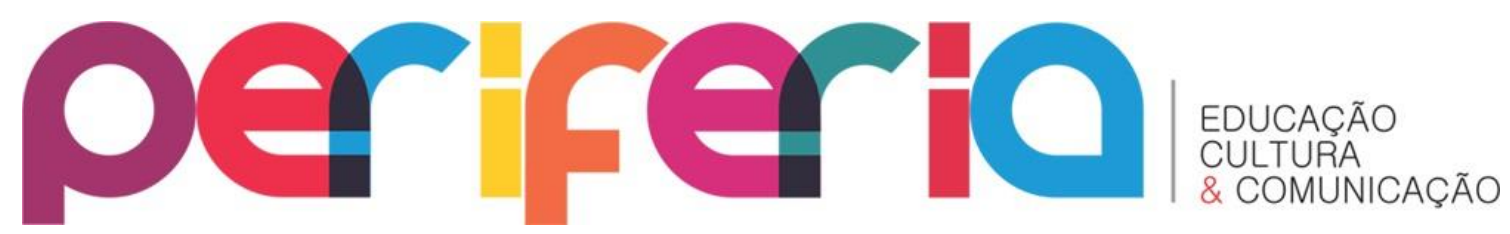

Outro bom exemplo é a coleção As aventuras de Luana, dos autores Aroldo Macedo e Oswaldo Faustino, publicada pela editora FTD. No primeiro livro da coleção intitulado Luana, a menina que viu o Brasil neném (2000), a heroína Luana, uma criança de 8 anos, na posse de seu berimbau mágico, leva crianças a outras épocas e conta detalhes da história de nosso povo valorizando a importância das diferentes culturas na construção de nossa nação.

Esses são somente alguns poucos exemplos que nos mostram como os personagens negros vêm sendo mais bem representados em obras infantis publicadas recentemente. Tanto educadores quanto responsáveis precisam adquirir um olhar mais crítico na escolha de leituras direcionadas às crianças. A busca de textos significativos que contemplem todos os segmentos da sociedade é essencial, de modo que o público infanto-juvenil consiga se ver, se sentir representado, por meio de imagens e estórias que contemplem e valorizem a diversidade independentemente da cor da pele de cada indivíduo.

\section{A CENSURA NOS ACERVOS LITERÁRIOS ESCOLARES}

Nas últimas duas décadas do século XX, surge uma preocupação maior com o teor do conteúdo dos livros infantis, especialmente devido ao fortalecimento dos movimentos negros mais recentes. Na realidade, as discussões acerca da censura na literatura, especialmente infantil, vêm tomando proporções gradativamente maiores. Questões de gênero, classe, raça, religião, orientação sexual, entre outras consideradas tabu em nossa sociedade deixam os autores pouco à vontade quanto à liberdade de expressão. Desse modo, os textos ganham críticas mais minuciosas e a linha entre o politicamente correto e o equívoco está cada vez mais tênue. Neste tópico, vamos nos ater à questão da censura racial, tema principal de nosso estudo.

Ao considerarmos a literatura como fator importante na formação tanto cultural quanto intelectual do sujeito, há de se preocupar com o que as crianças estão lendo ou o que estamos lendo para elas. Como a figura do negro teve sua imagem ora omissa, ora 


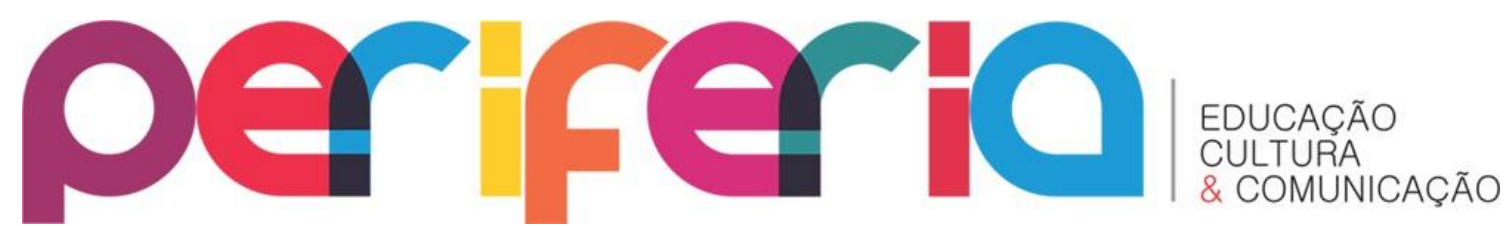

corrompida durante muitas décadas nas obras literárias, a escolha por livros mais adequados torna-se uma questão de discussão, principalmente para os profissionais de educação. Como saber se determinada leitura vai causar ou não desconforto para parte dos alunos? Ou mesmo incitar valores errôneos? Estarão os professores capacitados para lidar com a problemática racial em sala de aula? Ribeiro explica que a literatura infantil no geral:

Está carregadíssima de exemplos lamentáveis. Para a construção de um autoconceito favorável, é preciso que o ideal de ego não se mostre irrealizável, e fundamental para isso é o resgate da beleza, poder e dignidade das diversas etnias africanas. À criança afro-americana falta o modelo de Belo Negro. (apud SOUSA, 2001, p. 195)

Diante disso, permanece a dúvida quanto à exclusão de certas obras dos acervos literários escolares, pois, sabemos que o modelo de beleza e respeito à cultura negra que o autor destaca como importante simplesmente não existe em muitas delas. Do mesmo modo que na literatura infantil, os livros didáticos, não seguem caminho muito diferente. Segundo Silva, uma observação mais cautelosa também vem sendo feita nesses livros como a autora explica:

No que tange ao livro didático, denunciaram-se a sedimentação de papéis sociais subalternos e a reificação de estereótipos racistas, protagonizados pelas personagens negras. Apontou-se a medida em que essas práticas afetavam crianças e adolescentes negros/as e brancos/as em sua formação, destruindo a autoestima do primeiro grupo e cristalizando, no segundo, imagens negativas e inferiorizadas da pessoa negra, empobrecendo em ambos o relacionamento humano e limitando as possibilidades exploratórias da diversidade étnicoracial e cultural. (2001, p. 65 e 66)

Assim, observa-se ainda que, majoritariamente as imagens presentes nos livros didáticos não diferem muito dos literários, ou seja, os personagens negros são minoria ou estereotipados. Logo, as instituições escolares mesmo que inconscientemente, por meio do currículo e das obras literárias trabalhadas em sala, reforçam os ideais de beleza cristalizados pela maior parte da sociedade: o branco e loiro europeu visto como superior versus o negro de cabelos encaracolados, considerado feio e inferior. A escola 


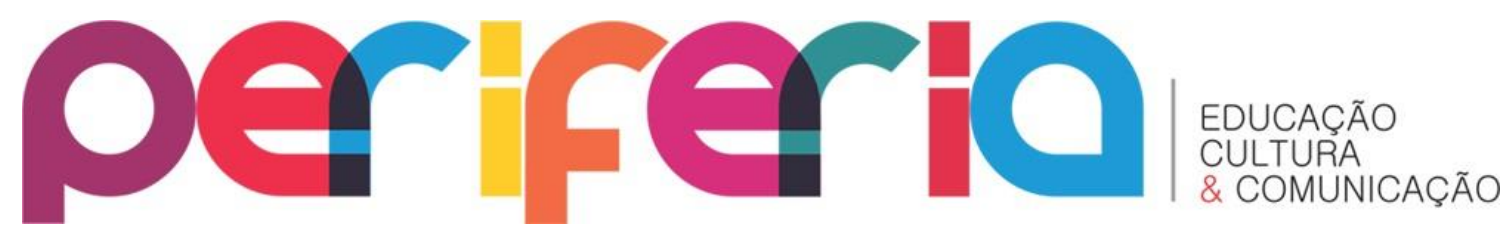

acaba não valorizando as diferenças no momento em que não abre espaço para a diversidade, marca histórica tão importante na constituição de nosso país.

No fim de 2012, uma polêmica racial envolvendo o livro Caçadas de Pedrinho de Monteiro Lobato chegou aos tribunais. A obra infantil integra o Programa Nacional Biblioteca na Escola (PNBE) e é distribuído para a leitura nas escolas públicas em todo território nacional. Porém em 2010, devido a uma denúncia feita a ouvidoria da Secretaria de Políticas de Promoção da Igualdade Racial da Presidência da República, questionou-se a permanência do livro no programa por seu conteúdo considerado por vezes racista.

O Ministério da Educação deixou claro que não iria censurar as obras de Lobato, nem outras obras de valor para a literatura infantil. No entanto, os detratores do autor afirmavam que o livro descumpre as regras de financiamento dos livros do PNBE. O programa alega em edital não aceitar financiar obras que contenham palavras que denotem preconceito ou reforcem estereótipos. Por isso, eles lutam, não pelo banimento da obra, mas no mínimo pela inserção de notas explicativas direcionadas aos educadores, esclarecendo que atualmente tais afirmações quanto aos personagens negros seriam crime, deixando isso claro na leitura para as crianças.

De qualquer modo, no fim de 2014, o Supremo Tribunal Federal rejeitou o pedido de suspensão do livro de Lobato. É importante ressaltar que a mesma obra já contém notas explicativas em conformidade com as Leis de crimes ambientais em um trecho onde as crianças se reúnem para matar uma onça. Logo, o crime contra os animais é devidamente sinalizado, no entanto o crime de racismo não.

Peter Hunt, autor do livro Crítica, Teoria e Literatura Infantil (2010), aborda o problema da adequação de obras antigas a questões hoje consideradas preconceituosas. Isso acontece porque essas representações são julgadas de modo distinto, de acordo com gerações e interesses diferentes. Há muito o que o que se considerar nos textos, principalmente a cronologia deles, visto que muitos nem eram direcionados a crianças ou pertenciam a um período com princípios e crenças completamente diferente dos atuais. Os contos de fada são bons exemplos de textos que foram originalmente 


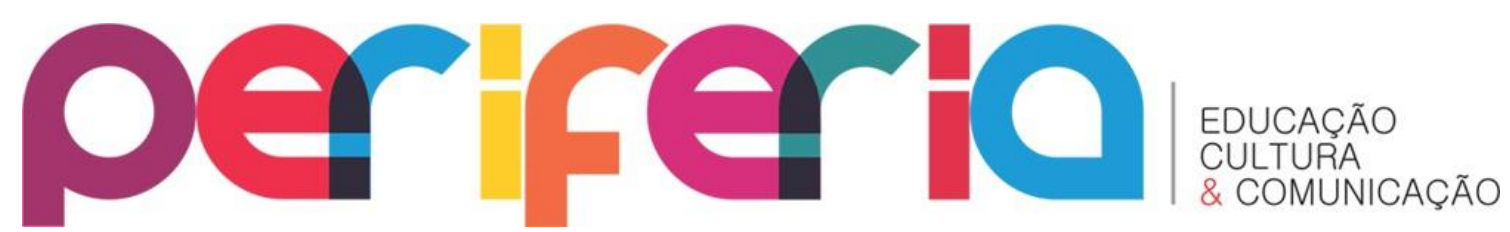

contados para adultos, e que seriam certamente considerados impróprios, caso fossem contados em suas versões originais para o público infantil hoje.

Isso tudo nos leva a algumas reflexões: afinal, o que é próprio ou impróprio para o público infantil? E quem será responsável por julgar esses fatores? Para Nodelman "Quando se trata de livros para crianças, já concluí que somos todos censores" (1992, p. 121)*. Em seu artigo intitulado We are all censors, o autor discorre sobre alguns pensamentos acerca da censura na literatura infantil. Ele afirma que as pessoas tendem a censurar somente aquilo que lhes desagradam ou seja, aquilo que vai contra seus valores pessoais. Segundo Nodelman, a censura é perigosa a partir do momento que nos dá direito a escolher o que o outro pode ler ou não. Sobre isso ele conclui:

Não há absolutamente nada que uma pessoa não deveria poder dizer ou escrever - nada, não importa o quão ofensivo, limitado, estúpido ou quão perigoso eu possa pessoalmente considerar. Nem coisas sexistas ou racistas. Nem equivocadas representações neo nazistas da história. Nem pornografia. Nada.*(1992, p.122)

No entanto, o autor deixa claro que, ao afirmar que todos têm o direito de dizer ou escrever o que querem, não significa que a escrita das pessoas não vá ser questionada. Para ele, se proibirmos o direito de escrever dos autores, perderemos a oportunidade de questioná-los e de saber verdadeiramente o que uma porção da sociedade pensa.

A censura de obras que não abrem espaço à diversidade racial ou que ferem de algum modo a identidade negra vem causando um fenômeno curioso no setor editorial, que são os chamados livros de encomenda. Isso acontece basicamente devido à escassez de bons livros que contenham personagens negros livres de estereótipos. O PNBE

\footnotetext{
* Tradução da autora, no original "When it comes to children's books, I've concluded, we are all censors."

* Tradução da autora. No original "There is nothing that anybody should not be allowed to say or to write - nothing, no matter how offensive, how narrowminded, how boneheaded, or how dangerous I might personally find it. Not anything sexist or racist. Not neo-Nazis misrepresentations of history. Not pornography. Nothing."
} 


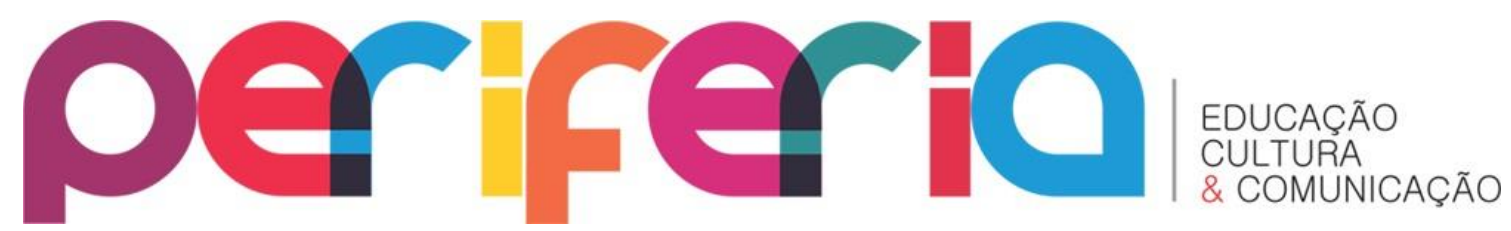

citado anteriormente é um exemplo de programa à procura de obras que explorem as culturas indígena e afro-brasileira. Esse aumento na demanda não acontece por acaso. Desde 2003, as reivindicações dos movimentos negros vêm ganhando espaço dentro das escolas com a sanção 10.639 alterando a Lei de Diretrizes e Bases da Educação com os seguintes artigos

Art. 26 - A. Nos estabelecimentos de ensino fundamental e médio, oficiais e particulares, torna-se obrigatório o ensino sobre História e Cultura Afro-Brasileira.

$\S 1^{\mathrm{a}}$ - O Conteúdo programático a que se refere o caput deste artigo incluirá o estudo da História da África e dos Africanos, a luta dos negros no Brasil, a cultura negra brasileira e o negro na formação da sociedade nacional, resgatando a contribuição do povo negro nas áreas social, econômica e política pertinentes à História do Brasil.

$\S 2^{\mathrm{a}}-$ Os Conteúdos referentes à História e Cultura Afro-Brasileira serão ministrados no âmbito de todo o currículo escolar, em especial nas áreas de Educação Artística e de Literatura e História Brasileiras. Art. 79-B. O calendário escolar incluirá o dia 20 de novembro como "Dia Nacional da Consciência Negra". (BRASIL, 1996)

Desse modo, observa-se que valorizar a identidade negra por meio da literatura tornou-se obrigatório. Por isso, a encomenda de obras com personagens negros, bem como adaptações de livros de sucesso a uma temática negra vem sendo incentivados pelas editoras. Um desses exemplos é Pretinha das Neves e os Sete Gigantes de Rubem Filho publicado em 2010. O texto é uma adaptação do conto Branca de Neve dos irmãos Grimm. As ilustrações feitas pelo próprio autor levam às crianças a um reino no continente Africano, onde todos os personagens são negros e as caracterizações de ambiente, costumes e hábitos remetem os leitores à cultura africana. Outra adaptação é A princesa e a ervilha (2011), da americana Rachel Isadora. Da mesma forma que Rubem Filho, a autora revisita o conto dos irmãos Grimm de mesmo nome, com texto e ilustrações que nos levam à África e suas belas paisagens.

Essas adaptações nos levam a questionar a encomenda do setor editorial. Com tantos textos originais disponíveis que já incentivam a valorização da cultura negra para o público infantil, seria realmente necessário adaptar textos europeus para atender à demanda do mercado por obras com personagens negros? Por que não incentivar a 


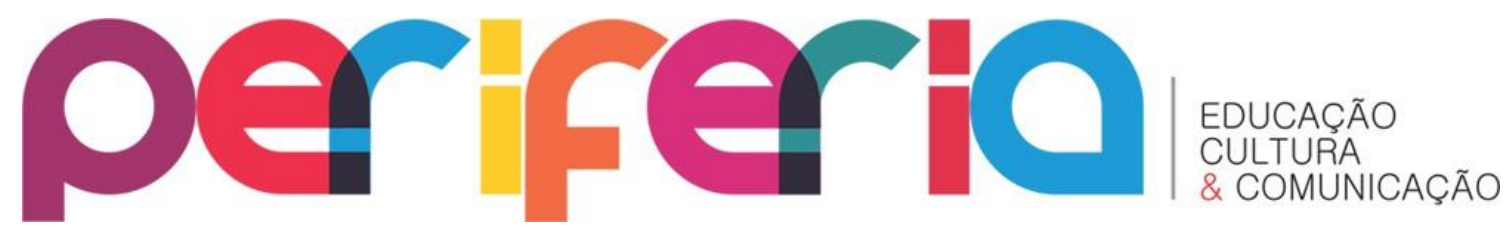

escrita de contos e histórias de origem afrodescendente em vez de reescrever e reilustrar textos que pouco tem a ver com a cultura negra?

O sociólogo Reginaldo Prandi vem publicando bons exemplares infantis de obras que contemplam a mitologia africana, as crenças do povo quanto as explicações para a origem do mundo e religião. Em A mitologia dos Orixás (2000) o autor reúne 301 relatos mitológicos sobre deuses africanos aproximando crianças e jovens de histórias de deuses como Iansã, Ogum, Exu, entre outros. Outras obras mais recentes como a trilogia Ifá, o adivinho (2002), Xangô, o trovão (2003) e Oxumarê, o arco-íris (2004) aborda alguns mitos dos deuses orixás, como também a apresentação de outros personagens míticos, herança que nos foi deixada pela cultura africana.

Outro autor que também trabalha com a cultura popular brasileira pela vertente das influências históricas dos povos negros no Brasil é Joel Rufino dos Santos. Ele escreveu diversos livros sobre histórias da África e do folclore brasileiro para crianças. Um deles é O presente de Ossanha (1997) que descreve a relação de amizade entre um negrinho escravo e o filho de seu senhor, um menino chamado Ricardo. A obra não vitimiza o personagem negro como também não esconde as relações de poder dos senhores de engenho com relação a seus escravos na época da Escravidão no Brasil. Além disso, mitos e deuses africanos são parte importante da estória que ajudam o pequeno escravo a ganhar força e lutar pela sua própria liberdade. Outros livros infantis do mesmo autor como A botija de ouro (1984), Dudu Calunga (1986), Gosto de África Histórias de Lá e Daqui (1998) são outras opções de trabalho com africaneidades em sala de aula.

Por fim, estamos longe de possuir dentro das escolas um acervo de fato democrático que contemple as diversas etnias que contribuíram para a formação de nosso país. O mito da superioridade da cultura do branco europeu sobre as outras culturas ainda é fortemente propagado em nossa sociedade imbricado pelo preconceito ou por concepções equivocadas de valor de raça e cultura. A leitura de livros que valorizem a identidade negra é positiva para nossos alunos independentemente da cor de pele que eles possuam. Assim, os alunos negros se sentirão representados enquanto os outros perceberão que a cor da pele não nos faz diferentes, pois também somos iguais 


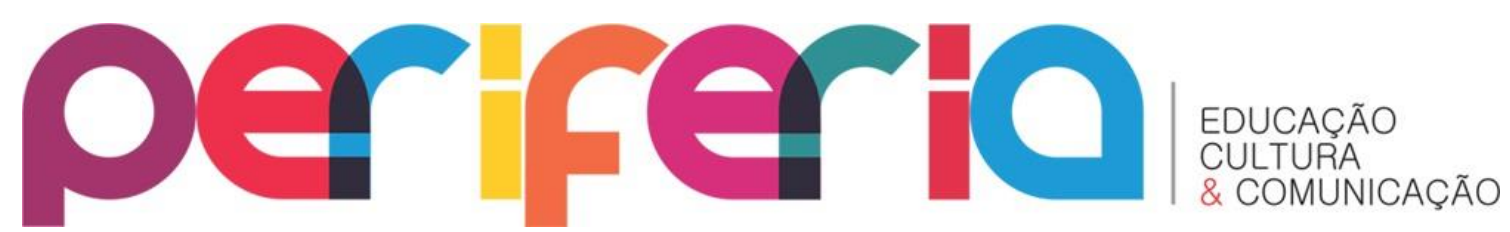

nas diferenças. Censurar obras que tratem os personagens negros de forma ultrapassada, negligenciada ou estereotipada é a única opção para aqueles que acreditam que este é o caminho certo a se seguir especialmente na literatura infantil. Enquanto isso, os anticensores pensam de modo diferente e afirmam que a leitura de um texto preconceituoso não nos torna automaticamente preconceituosos bem como ler um livro com histórias violentas não nos faz pessoas agressivas. Pelo contrário, ao lermos algo com o qual não concordamos, ganhamos a chance de pensar criticamente e reconhecer opiniões muitas vezes veladas, porém presentes em nossa sociedade.

\section{CONSIDERAÇÕES FINAIS}

Observamos que a valorização da infância e as inúmeras questões que lhe são pertinentes podem ser consideradas uma preocupação relativamente recente e ainda permeada de muitas dúvidas. Ao longo de nosso estudo, foi possível observar que as considerações mais atuais sobre o mundo infantil mudaram a forma como pensamos, analisamos e criticamos praticamente tudo relacionado a esse tipo de público, em especial a literatura. Consequentemente, essas mudanças influenciaram diretamente um maior cuidado, até mesmo uma possível censura na leitura de obras consideradas inadequadas por pais e professores.

De fato, o nosso foco principal de análise foi a representação dos personagens negros ao longo dos anos nas obras infantis. Foi possível observar que as personagens negras praticamente inexistem nas obras literárias até o fim da escravidão, reproduzindo assim a suposta invisibilidade dos negros para a sociedade de supremacia branca. Estas só começaram a aparecer nas páginas dos livros no início do século XX - o que é bastante recente. Mesmo assim, por muitos anos tivemos a caracterização do negro ainda como se ele fosse escravo, comumente representado em modelos subservientes, bestializados ou inferiores. Com o avanço dos movimentos de luta contra o preconceito racial no país, a comunidade negra tem buscado voz em meio a nossa sociedade, que é ainda muito influenciada por padrões de beleza e cultura europeia. 


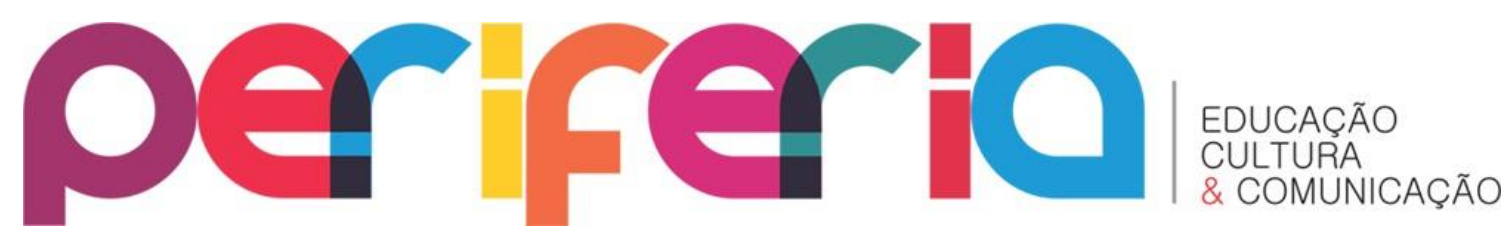

A interação com livros que valorizem a cultura negra é importante para todas as crianças, independentemente do seu pertencimento étnico-racial, a fim de desmistificar essa suposta superioridade do branco sobre o negro. É importante quebrar esses paradigmas que foram praticamente cristalizados pelo tempo e darmos voz à cultura afrodescendente em suas diversas ramificações estéticas, artísticas e históricas, que são tão ricas e fundamentais na formação étnica do nosso país, fornecendo a criança negra modelos positivos e reais de representação tanto nas ilustrações quanto nos textos infantis.

Ao utilizarmos a literatura como importante função social, procuramos através dela sensibilizar nossos alunos, e tornar possível para a criança criar e recriar seu mundo de forma criativa. Para isso, cabe a nós educadores o cuidado na leitura de obras com teor racista, principalmente as que foram escritas em uma época onde taxonomias raciais ainda eram levadas em consideração. Tais livros não precisam ser necessariamente excluídos de nosso repertório, caso sejam de qualidade, mas servem como crítica e incentivo a conversa sobre temas como valor, justiça e respeito, despertando nos pequenos desde já um melhor julgamento quanto aos padrões e ideias ainda preconceituosas promulgadas pela nossa sociedade.

\section{REFERENCIAS}

ALMEIDA, Gercilga de. Bruna e a Galinha D'angola. Rio de Janeiro: Editora: Pallas, 2000.

BRASIL. Lei de Diretrizes e Bases da Educação Nacional. Lei número 9394, 20 de dezembro de 1996.

CASTILHO, Suely Dulce de. A Representação do Negro na Literatura Brasileira. In: Novas Perspectivas Olhar de Professor, Departamento de Métodos e Técnicas de Ensino Paraná, Brasil, vol. 7, núm. 1, 2004, p. 103-113.

FILHO, Rubem. Pretinha das Neves e os Sete Gigantes. Rio de Janeiro: Editora Paulinas, 2010.

GIAROLA, Flávio Raimundo. Racismo e teorias raciais no século XIX: Principais noções e balanço historiográfico. História e-História, v. SM, p. 1-21, 2010. 


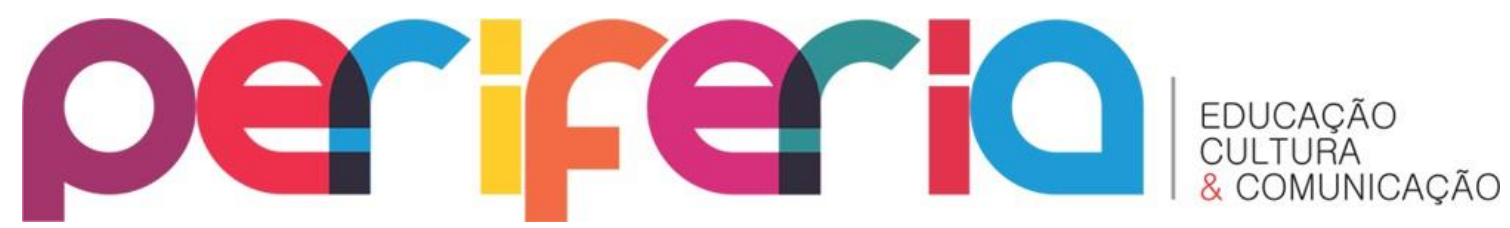

GOUVÊA. Maria Cristina Soares de. Imagens do negro na literatura infantil brasileira: análise historiográfica. Educação e Pesquisa, São Paulo, v.31, n.1, p. 77-89, jan./abr. 2005.

HUNT, Peter. Crítica, Teoria e Literatura Infantil. São Paulo: Editora Cosac Naify, 2010.

ISADORA, Rachel. A princesa e a ervilha. São Paulo: Farol literário, 2011.

LOBATO, Monteiro. Histórias de Tia Nastácia. São Paulo: Ed. Nacional, 1937.

MACEDO, Aroldo; FAUSTINO, Oswaldo. Luana, a menina que viu o Brasil neném. Rio de Janeiro: FTD, 2000.

MACHADO, Ana Maria. Menina bonita do laço de fita. São Paulo: Editora Ática, 1988.

NODELMAN, Perry. We are all censors. Canadian Children's Literature 68 (1992): p. 121-133.

PRANDI, Reginaldo. A mitologia dos Orixás. São Paulo: Companhia das letrinhas, 2000.

.Ifá, o adivinho. São Paulo: Companhia das letrinhas, 2002.

Xangô, o trovão. São Paulo: Companhia das letrinhas, 2003.

. Oxumarê, o arco-íris. São Paulo: Companhia das letrinhas, 2004.

SANTOS, Joel Rufino dos. A botija de ouro. São Paulo: Editora Ática, 1984.

. Dudu Calunga. São Paulo: Editora Ática, 1986.

O presente de Ossanha. São Paulo: Editora Global, 1997.

. Gosto de África - Histórias de Lá e Daqui. São Paulo: Editora Global, 1998.

SILVA, Lucina Cunha; SILVA, Katia Gomes de. O negro na literatura infanto juvenil brasileira. Revista Thema, vol. 8, número especial, p.1 - 13, 2011.

SILVA, Maria Aparecida da. Formação de educadores/as para o combate ao racismo: mais uma tarefa essencial. In: CAVALLEIRO, Eliane (Org.). Racismo e anti-racismo na educação: repensando nossa escola. São Paulo: Selo Negro, 2001.

SOUSA, Andréia Lisboa de. Personagens negros na literatura infanto-juvenil: rompendo estereótipos. In: CAVALLEIRO, Eliane (Org.). Racismo e anti-racismo na educação: repensando nossa escola. São Paulo: Selo Negro, 2001. p. 195-217.

SOUZA, Jessé. A Ralé Brasileira: Quem é e como vive. Belo Horizonte: Editora da UFMG, 2011.

ZIRALDO. O menino marrom. São Paulo: Melhoramentos, 1986. 